Henry James's Suspended Situations

Review by: Omri Moses

Modern Philology, Vol. 108, No. 1 (August 2010), pp. 116-150

Published by: The University of Chicago Press

Stable URL: http://www.jstor.org/stable/10.1086/656398

Accessed: 20/01/2014 09:49

Your use of the JSTOR archive indicates your acceptance of the Terms \& Conditions of Use, available at http://www.jstor.org/page/info/about/policies/terms.jsp

JSTOR is a not-for-profit service that helps scholars, researchers, and students discover, use, and build upon a wide range of content in a trusted digital archive. We use information technology and tools to increase productivity and facilitate new forms of scholarship. For more information about JSTOR, please contact support@ jstor.org. 


\title{
Henry James's Suspended Situations
}

\author{
OMRI MOSES \\ Concordia University
}

I think he [Henry James] has about the keenest sense of Situation of any novelist.

(T. S. Eliot to ElEAnor HinkLey, April 1, 1918)

If one wanted to characterize the oddity of Henry James's way of staging characters in his late long novels, one could do worse than to note how little we are told of the characters' motives or intentions-especially when it comes to their most imposing aims and plans. Ordinarily with a psychological novel, one does not need to read an express purpose in order to infer one. Narrative reticence merely obliges one to conjecture from a repertoire of probabilities and then to choose the likeliest, pending further confirmation. James's interpretive protocols are somewhat different. It is not that The Golden Bowl (1904), for instance, fails to invite inferences about a character's motives or intentions. But one gets an impression that those motives are tied, to an unusual degree, to the moment-by-moment unfolding of a situation rather than to some desire or fact hidden behind it. Maggie Verver and Charlotte Stant do not allow themselves any desire that is not contingent on the situation that emerges before them. Because their feelings are adapting to circumstances that are never entirely fixed, they would seem to flicker before us without giving their possessors the smooth, rounded outline of consistent beings. James's characters discover themselves in their own conversations, which trace the contours of the situation that gives substance to them.

To say that James is a "situational" novelist is already to remark upon something basic that distinguishes him from other novelists of his time. Each of his characters is so profoundly relational that she or he cannot be bound to any independent-which is to say, preestablished and recurring-form of being. The contention that James launches situationally defined characters, I am well aware, goes contrary to the models of person-

I would like to thank Charles Altieri, Kaja Silverman, Mary Esteve, Justus Nieland, and my anonymous reviewers for their wonderfully insightful suggestions and advice at various stages of the present essay's construction.

(C) 2010 by The University of Chicago. All rights reserved. 0026-8232/2010/10801-0006\$10.00 
hood that hold high currency in our culture. We assume that people derive their psychological consistency from a set of dominant traits that, whether visible or not, provides them with an identity that cannot easily be surmounted or swept away. The complexion of their desires and tendencies of thought would, so long as we presume their regularity, sooner or later be made to reveal linkages to the formative events of their life, or else to their inherited traits. One might call these substantialist models of character. However much one model varies from another in its details, they all presuppose that people make large-scale adjustments to their situation that are regulated by intractable preferences and fixed patterns that emerge from outside the situation at hand and transcend it. James's characters, by contrast, obtain their consistency from their continuous engagement with succeeding social environments with which they are obliged to interact. Their reactions have real repercussions for themselves and others around them, and the powers of perception and willpower that they wield shape them in meaningful ways. And yet while they continually change, they remain in an unbroken relation with their past instantiations.

I do not want to say, exactly, that James sweeps away all "interior" content from his characters-all desires or consistent intentions. But whatever elements of character he fixes from the start are neither a sufficient basis for his fiction nor a satisfactory representation of character itself. There are ample examples of Jamesian characters whose desires remain constant and unquestioned even as circumstances change. Maggie's love of Prince Amerigo, unaltered throughout The Golden Bowl (1904), is one. But such desires are merely preliminary. They do not "signify" of themselves and only come to mean something important about the personages who harbor them when placed in a dynamic context. While James grants his characters their donnée, he does not invite readers to interpret or excavate the deep causes underlying their actions. Patterns of causes are-we are left to gather-taken for granted, and therefore uninteresting, apart from the situation in which those determinants are made use of or tested.

In James, characters come alive only at the point when, in response to a situation, a vital hesitation suspends or transforms an initial intention or, indeed, fails to. To get a sense of his abandonment of cause and fixity in favor of vital adaptability, one need only consider the double-dealing plot design of The Wings of the Dove (1902), wherein Kate Croy concocts a plan to marry off Merton Densher, her flame, to a wealthy heiress whom she knows to be mortally ill. As James says in one of his letters, the understanding between the two is "in its explicitness simply the subject of the book." "James's deeper interest lies in how characters dispose themselves

1. Henry James to Mary Humphry Ward, September 23, 1902, in Henry James: A Life in Letters, ed. Philip Horne (New York: Viking, 1999), 372. 
in relation to their desires the moment another subjectivity enters the equation-in this case, Milly Theale, with all her needs and vulnerabilities. Kate's persisting in her intention is a reflection, it would seem, of a wondrously opportunistic will that crystallizes in the midst of her experience. Her intentions are activated and modified by their placement in a complex situation in order for them to endure across time. Though quite definite, they are a preamble to an improvised response.

More often than not in James's last novels, intentions and motives seem belated or halfhearted, expressing only a tendency to act in a certain way or to pursue a specific direction of thought; they are not fully formed purposes. James is, on the whole, an unpsychological psychologist in that he refuses to make the psychological reduction that translates impulses into preordained rationales-that projects onto tendencies a retrospective finality or that reads the future with the mistaken neatness of the past. For reasons clarified below, I draw here on the psychological fallacy that James's contemporary, the philosopher Henri Bergson, associated with analytical models that conflate tendencies, or in his terms élan vital, with purposes. He suggests that we are apt to confuse the end with the road itself, but "the road has been created pari passu with the act of traveling over it, being nothing but the direction of this act itself. At every instant, then, evolution must admit of a psychological interpretation which is, for our point of view, the best interpretation; but this explanation has neither value nor even significance except retrospectively."2 For Bergson, interpretations that seek a fixed order in all things suit certain practical human needs, but only by distorting the actual nature of unfolding events.

Critics who have understood James as doing away with substantialist conceptions of character have often interpreted his intricately wrought formal experiments as a way of transcending the limitations imposed by the structure of character itself, tending to regard his formal resolutions as substitutes for fully engaging human problems. In what follows, I question this move to depose character from being the ultimate seat of reckoning for negotiations of conflict in James.

My aim in this essay is to examine some of the objections that James raises to prevailing moral and psychological ideals of consistency. I suggest that rather than simply doing away with character, he dissolves the standard of consistency traditionally applied to moral entities and refashions their modes of unity and individuation in ways that are unexpected but ultimately psychologically and ethically compelling. We will begin, then, by asking what the imagined personages in James's complex novels tell us about what it means to be a person. One key element of 
concern will be his characters' fluid identifications, emotive capacities, and ad hoc impulses, which allow them to adjust to their circumstances rather than be moored to a dominating past. It would seem that his protagonists withstand any impulse to fortify or retrench psychic life and thus decline to insulate themselves from others.

To be sure, it is hard to get around the feeling that James confers upon characters a malleability we do not normally expect of people. Their consistency seems strangely "superficial" - prescribed by details of the moment and not by the deeper personal identity typically evoked in the nineteenthcentury novel. ${ }^{3}$ The superficiality I am alluding to does not refer to a trivial quality of person but to a responsiveness that James's characters show to the very surface of social life and its webs of signification. The interest held by these complexities largely displaces the reader's need to probe the inner machinery of their personality (throughout I am using the term "personality" to denote the structure underlying self). It is difficult to locate an abiding quality of moral purpose connecting their behavior to principles sponsored and strengthened by the self's previously established integrity.

In order to account for this phenomenon, we need a psychological model that makes allowances for the self-inventive capacity of people while still pegging selfhood to nontrivial forms of material and social constraint. In the latter half of my argument, I enlist the aid of certain psychological accounts developed during the period by the intellectual practitioners of "vitalism." Critics have underestimated the relevance of this discourse to James's understanding of character, despite the central role that his own brother, William James, had in its development. This essay will consider Henri Bergson and William James by turns, both of whom emphasize an action-oriented account of agency while discarding models that presume that there is some set identity at the core of self. Each figure welcomed and supported the other's work-as many of their letters attest-but the linkage has not been an object of much critical attention, nor have scholars established the central contribution that William James's brother, Henry, makes to vitalistic paradigms of character. ${ }^{4}$ The Golden Bowl is my prevailing case; its four principal protagonists

3. What I am calling superficial is a specifically psychological quality of character and not a tendency to foreground the objects of the concrete material world-the subject of Thomas Otten's A Superficial Reading of Henry James: Preoccupations with the Material World (Columbus: Ohio State University Press, 2006).

4. William James writes to Bergson that Pragmatism, the book he is sending him, is "jejune and inconsiderable" but so "congruent with parts of your system, fits so well into interstices thereof, that you will easily understand why I am so enthusiastic. I feel that at bottom we are fighting the same fight" (William James to Henri Bergson, June 13, 1907, in The Correspondence of William James, ed. Ignas K. Skrupskelis and Elizabeth M. Berkeley, 12 vols. 
demonstrate a capacity to fashion compelling new identities by putting their established attitudes on hold and readjusting their relations to one another. These personages take their signals not from the past but from the virtual future, that is, from the opportunities that they discern or create in the situation cast before them.

By invoking Jamesian vitalism rather than pragmatism, I wish to suggest more than that "the 'self' is merely another transitional agency, a progressive unfolding that is at the same time an ongoing reflection on that unfolding." Though Jonathan Levin's incisive quasi-Spinozan formulation here emphasizes Henry James's interest in process, in the "drama of transition," over any substantive conclusion afforded us as readers, it says little about why transitions in experience are meaningful or what aspects of agency they liberate. ${ }^{5}$ In other words, Levin misses an opportunity to place these transitions within a larger account of grounds for ethical comportment in James's novels. Like other critics whom we will examine more directly, principally Leo Bersani and Sharon Cameron, he would rather not situate this unfolding perception in any specific locus of consciousness. Instead, I foreground James's commitments to realism in order to explore the link between his psychological conception of character and his vision of ethical life.

For the last sixty years, the tendency to approach character as a fictive element in a structure has been central in attempts to reflect on characterization. Long after narratologists started referring to characters as "actants" and "existents," classifiable by the range of predictable roles, types, and actions they represent, literary critics have emphasized formal or structural analysis. ${ }^{6}$ By contrast, I suggest that Henry James's fascination with psychic variability can contribute to our conception of what a person is. For this reason, one might endeavor to repsychologize James's characters, treat them in a manner that is different in kind from merely asking how they mimic or predict real people's behavior within a certain

[Charlottesville: University Press of Virginia, 2002], 11:377). Bergson responds after reading Pragmatism: "Pour ma part, je n'ai jamais mieux saisi l'affinité qui existe entre nos deux méthodes de penser" (For my part, I never understood better the affinity that exists between our two methods of thinking) (Henri Bergson to William James, January 27, 1908, ibid., 11:531, my translation).

5. Jonathan Levin, The Poetics of Transition: Emerson, Pragmatism, and American Literary Modernism (Durham, NC: Duke University Press, 1999), 118, 117.

6. As Thomas Petruso argues, these methodologies display elaborate formalisms that displace issues of characterization, not as L. C. Knights did by favoring "literary" concerns with metaphor and imagery, but by focusing on the "tensions" and "anxieties" of the text itself rather than the people within it (Thomas Petruso, Life Made Real [Ann Arbor: University of Michigan Press, 1991], 3). See also L. C. Knights, "How Many Children Hath Lady Macbeth?" in Further Explorations (London: Chatto \& Windus, 1965), 1-39. 
range of experience, how they flesh out thematic and formal issues, or how they fit with symbolic typologies. ${ }^{7}$

Recently, Alex Woloch has attempted to chart a sophisticated middle pathway between structuralist views of character as codes or allegorical features within a "distributional matrix" and an earlier character criticism that focused on individual psychologies irrespective of placement within the narrative. His "synthetic" theory of literary character prefers to speak about character-spaces and character-systems-that is to say, about how fictive individuals get positioned within a narrative frame and how their positionings intersect to create social configurations. ${ }^{8}$ These social configurations suggest communities of individuals vying for acknowledgment within a social space. In his view, the depth or complexity of a character is rendered by the quantity of narrative attention granted to it or by the number of minor characters that are sacrificed on that character's behalf. I would argue, though, that he attends insufficiently to the specific individuating qualities that emerge as these "implied people" respond to one another. While characterization cannot happen in the absence of rigorous formal arrangements, the interpretive dictates also need to emerge out of something other than narrative imperatives. In focusing on characters' makeshift and extemporized acts, we will consider modes of characterization that cannot be classified or explicated solely or even primarily in terms of plot function and structural tension.

In The Golden Bowl and The Ambassadors (1903), James calls particularly acute attention to the incipient features of his protagonists' activitiesthe way these characters come to focus on a thing before they know exactly what they are focusing on, or why. Dramatizing their leaps of thought, James suggests a mind so overwhelmed by the possibilities it perceives all around it that it has to remain perpetually alive to those possibilities. Strether's principal problem in The Ambassadors, as he comes to see it, is that he has to keep pace with the change he discovers in Chad: "What it came to was that with an absolutely new quantity to deal with one simply couldn't know [how to appraise him]. The new quantity was represented by the fact that Chad had been made over." For this reason, "Strether

7. Judith Ryan, for example, turns characters in Henry James's Golden Bowl into allegorical stand-ins for vying psychological discourses rather than considering their individuating qualities as they emerge in a specific situation, the real starting point for a Jamesian modernism (Judith Ryan, The Vanishing Subject: Early Psychology and Literary Modernism [University of Chicago Press, 1991]). She is, however, one of a very few critics to explore in any detail the relation between late nineteenth-century trends in empirical psychology and modernist literary production. She focuses on such things as modernists' presentations of consciousness and sensory perception as they relate to various empirical and positivist models developed by Franz Brentano, Wilhelm Wundt, William James, and Ernst Mach.

8. Alex Woloch, The One vs. the Many: Minor Characters and the Space of the Protagonist in the Novel (Princeton University Press, 2003), 13, 19. 
didn't, as he talked, absolutely follow himself; he only knew he was clutching his thread and that he held it from moment to moment a little tighter."9 Strether may try to pursue his appointed task, to retrieve Chad from the clutches of Europe, but the somewhat desperate effort he makes is beset with difficulties. Strether is like Maggie, Densher, and Maisie: each of their situations is constantly in movement and requires responses of them before they have a chance to process unfolding events.

James does not withhold from us information that such characters have about their own actions-certainly not in the same way, say, that a mystery novel or a piece of detective fiction would. These characters themselves do not have premeditated intentions, or if they do, their ensuing aims are vague, tentative, and contingent upon events. The prototypical Jamesian character is not simply looking for the best means or instruments for realizing his or her intentions. He or she has in fact to modify desire itself-and the intentions that result from it-in order to be able take advantage of all the forces that enable action. For James, as for Nietzsche, the iron force of will consists not in arbitrarily triumphing over a situation but, rather, in aligning oneself with its contingencies and using that horizon of expectation as a basis both for acting and, to some degree, for wanting. Pursuing a wish for something outside the limits of any situation is idle if not dangerous, inasmuch as it stokes a fantasy about voluntaristic agency that leads to a benighted form of detachment. Desire is more labile for James's characters-not infinitely flexible, but open enough to allow characters to tune their feelings in accord with their perception of events, to play them out in conversation, and to strengthen some elements at the expense of others.

While I would argue for the validity of these claims across Henry James's late works, they emerge with particular salience in The Golden Bowl. To the degree that there is a plot, it conforms to the terms of a garden-variety adultery romance. The novel opens with Prince Amerigo, an impoverished Italian nobleman on the cusp of marrying Maggie Verver, the daughter of a very wealthy American businessman. Charlotte Stant, a school friend of Maggie's who has had an intimate relationship with the prince unknown to Maggie herself, arrives in London for the wedding with intentions that are not entirely clear. Her relationship with Amerigo was called off prior to the latter's acquaintance with Maggie; Charlotte herself is penniless, and despite her fervid feelings for the prince, financial matters make the liaison impracticable. Charlotte arranges to meet her former lover with the ostensible objective of buying a present for her friend, his soon-to-be wife, but also to spend one last afternoon with him before his wedding. Maggie is to be told nothing of the outing. Time 
passes. Maggie gives birth to a son, and Charlotte returns to London. Remaining poor, and at the behest of various benefactors, Charlotte ends her silent wretchedness by marrying Maggie's father. With this preliminary framework of dual entanglement established, the novel subsequently concerns itself with the making and unmaking of the affair that sparks up between Charlotte and Amerigo.

The affair becomes the occasion for James to explore an intricate situation that invites characters to consider numerous avenues of possible response. Each action on the part of his characters is, in James's hands, weighted and compounded with proliferating extensions of meaning, and therefore any inferences on our part as to why they do what they do from one moment to the next are hardly self-evident. Indeed, each strand of the situation is dependent on reciprocated understandings that have yet to firm up. Of course, the novel is in some sense "about" an affair in the making, with all the requisite instances of intentional lying and masking that such a plot demands. Yet critics have a tendency to exaggerate and even misconstrue the sense of conscious purpose in Charlotte and Amerigo's elaborate subterfuge. One might legitimately ask whether Charlotte marries Adam Verver to get close to the prince, but the answer is not straightforward. What Charlotte is "really thinking" when she wrestles with the idea of marrying the millionaire is impossible to discern-for her and for us-outside of her reaction to individual circumstances.

Such characterological suspension is on view in one of the novel's understated prick points, when Adam Verver sets about to learn why Charlotte so tenaciously postpones her acceptance of the marriage proposal he has advanced. Verver, building upon, elaborating, and perhaps just a touch justifying his proposition, tells her, when faced with certain as yet unclear resistances, that he anticipates Maggie's pleasure with the engagement. Maggie, he thinks, believes her father will in general benefit from being married, even going so far as to put forward that "it's her idea —!":

This enunciation of motive, the next moment, however, sounded to [Adam Verver] perhaps a bit thin, so that he gave it another touch. "That is if it's my idea [for marriage]. I happen, you see, to like my idea."

"Well, it's beautiful and wonderful. But isn't it, possibly," Charlotte asked, "not quite enough to marry me for?"

"Why so, my dear child? Isn't a man's idea usually what he does marry for?"

Charlotte, considering, looked as if this might perhaps be a large question, or at all events something of an extension of one they were immediately concerned with. ${ }^{10}$

10. Henry James, The Golden Bowl (New York: Wordsworth, 1995), 133, hereafter cited parenthetically as $G B$. 
In this stunning scene, Charlotte is navigating the stresses and values of different implications that the proposal has for her (the extenuating circumstances, large and small, that concern her). She appears to hedge at this moment. Is she worried about Amerigo's reaction to the news of his former lover's engagement with his father-in-law-his sense of the complications or temptations? Is she simply afraid of a snub from him at a moment when she expects to be able to cinch her grip around him? Or is it that her enduring attachment to the prince makes her balk at this new opportunity? On the other hand, how convincing is this proposal, an indication of future commitment on the part of her admirer, which places such emphasis on his daughter's feelings rather than his own? James's point, I submit, is not to have the reader settle on one or several answers to the questions but to see the situation as one susceptible to different forms of anchoring, different ways of suiting and arranging implications, thus as itself open, in wait of future relations that have not yet formed or hardened. One inevitably asks the questions, but only to track the possibilities suspended there before one. Charlotte seems not to have finished deciding at this moment where exactly to place her hope-with the Amerigo or with Adam Verver. After receiving a telegram from Amerigo, it is true that Charlotte quickly consents to the proposal. Even here, though, she seems as much in search of intentions as readers are. The telegram, ambiguous as it is, only manages to keep open the possibilities that she needs to sustain in order to pledge herself; or rather, it relieves her of worries that might have been too much for her already ambivalent position.

Charlotte is not a completely cynical actor, even if one may be tempted retrospectively to construe her as such. To be sure, when we next see her, she is pursuing the prince with evident confidence. But two years have passed, and certain possibilities have presumably ebbed and evaporated: her husband's hinted-at impotence has squelched any prospect of sexual intimacy with him and, along with it, the chance of having children. She quickly neutralizes Fanny, who poses one of the chief obstacles to her designs, turning her innuendo about liberties taken and proprieties broken into flat acknowledgment of the case at hand-thus giving her no recourse for protest or threat. All the same, Charlotte has, as Fanny later remarks, "so remarkably much" to say for herself about the conditions of her marital bargain $(G B, 165)$. She is not simply plowing her way through to the desired conclusion. She cares a great deal about how she pursues the affair. Indeed, she preserves a lucid accounting of all the people to whom she is still accountable, as well as all the relations that have brought her to her present crisis.

Even in those moments when Charlotte's intentions look obvious, they are still only preliminary. What gets foregrounded is a certain wait-and- 
see attitude on her part. She may go about with the obvious intention of securing a more confidential proximity to Amerigo and, in the meantime, rid herself of Fanny, but she has yet to discover how she can fit herself, her desires, her sense of her position, into a brokered compromise. As part 3 opens, she is quite literally suspended "half way up the "monumental' staircase" at an ambassador's party, flourishing herself in such a manner as to present-to Fanny, to Fanny's husband, to herself-what her fluid situation, "imperfectly articulate," presents for her $(G B, 146)$.

James's readers have sometimes been befuddled by the odd mixture of overt motives and temporizing evasions expressed by characters in his later fiction. Van Wyck Brooks early on complained of their mystifying behavior, which "bears no just relation to the motives that are imputed to them.... Magnificent pretensions, petty performances!- the fruits of an irresponsible imagination, or a deranged sense of values, of a mind working in a void, uncorrected by any clear consciousness of human causes and effects."11 I propose, though, that relatively secure motives can coexist with a specific kind of irresolution. First of all, James shows that desires are multiple and sometimes contradictory. Situations help prioritize those desires, but they also elicit impulses that are unforeseeable and that lead in improbable directions-or that solicit action without demanding a complete map of possible ends. Sometimes what James's characters find uncertain are not the specific attitudes they may hold or the intentions they harbor but the way to put them to work, particularly when other people are at issue. His interest, then, is in the sorts of cases where attitudes and values somehow jar with the particular situations they are called upon to referee-and where the characters who harbor them are changed by the experience they run into. The little shocks dramatized in James's novels are nothing but friction points, moments when characters are forced to adjust to their situations, and situations, in turn, test the capacities of characters to alter and rework them.

\section{SUPERFICIAL CHARACTERS, CENTERED SELVES: THE CASE OF GEORGE ELIOT}

In order to appreciate fully the importance of James's conceptual renovation of character, it may be instructive to look at important realist models of character in circulation at successive stages of his career as a writer. I consider, first, the case of George Eliot, whose precedent James admired but distanced himself from; and second, that of Joseph Conrad, whose situations and impulse-driven characters often draw critical comparisons with James's own, to somewhat misleading purpose. Eliot, like Conrad, 
promotes critical paradigms that search for the secret unmovable centers guiding and motivating behavior. One may gauge the distinctiveness of Jamesian modernism by the novel interpretive frames of reference he brings to bear on character analysis and, as I will eventually argue, by the "suspended" situations he presents for readers' contemplation. These situations force one to navigate an unprecedented, because highly particular, constellation of relations that yields no stable interpretive framework on which to judge it.

Consider the following moment from Middlemarch (1871-72), where Eliot ratchets up the central conflict in the book, between the ingenuous Dorothea, whose morally uncalculating nature leads her to grandiose marital misreckoning, and the brittle, stony Mr. Casaubon:

We are all of us born in moral stupidity, taking the world as an udder to feed our supreme selves: Dorothea had early begun to emerge from that stupidity, but yet it had been easier to her to imagine how she would devote herself to Mr. Casaubon, and become wise and strong in his strength and wisdom, than to conceive with that distinctness which is no longer reflection but feeling - an idea wrought back to the directness of sense, like the solidity of objects-that he had an equivalent centre of self, whence the lights and shadows must always fall with a certain difference. ${ }^{12}$

The "certain difference" of which Eliot speaks is the unequivocal division that separates one person from another, and it presumes a certain persistency with which each goes on being who he or she is. Characters in her terms enjoy solidity. They are capable of casting shadows and are subject, emotionally and physically, to the laws pertaining to things that endure in their own separate nature. What is more, Eliot's protagonists are ranked as separate-and equivalent—centers, but what makes them a center is not a point of view or a specific responsibility all their own, formed by virtue of their present position in a social configuration. Rather, they are centers on the basis of their abstract status as moral beings, with obligations accruing to them accordingly, or else because they are subject to the constraints of their appointed nature. Dorothea's bright expectancy, Eliot implies, cannot long withstand the erosions of an incompatible alliance, which reveal to her only the massive outline of her husband's shadowy difference from her.

Of course, the passage I cite is erected around a metaphor, and its indirectness as well as narrative location leaves open the possibility that Casaubon is not quite as solid and self-sufficient as Dorothea here believes. Middlemarch is, after all, ultimately about the interconnections that subtly and 
invisibly constitute social life. The metaphor goes a fair way to undermining itself by suggesting that elements of character are assessed not by themselves but only analogically, relationally (one person set against another)and would be hard to understand outside of the linkages and contrasts that seem to reveal them in social life. Dorothea's knowledge either of herself or of her husband is not possible except as knowledge within a relationship, discovered by an act of feeling or inference.

Neil Hertz's reading of this passage in George Eliot's Pulse casts off the implication that this moment of awakening is the novel's final say. He suggests that Dorothea's emergence from moral "stupidity" is unavoidably incomplete. As he says, "To be born in moral stupidity is to be born imaginative; and it is against the inertia of this mode of imaginative activity, the narcissistic dwelling on and in an image, that the moral imagination has both to define itself and defend itself." ${ }^{13}$ His argument seems to be that, for Eliot, moral life requires that one recognize people in their differences, but at the same time one cannot be allowed to remain wholly detached from them, or one risks blindness to the very principles that draw one into a human community with others. Thus the very narcissism that Dorothea invites also brings with it a measure of truth, insofar as people are not quite so disconnected from each other as she may, at this moment in the novel, wish to believe: "The difference between the two kinds of imagination ... may not, under scrutiny, be all that clear." In any case, Dorothea cannot simply "cast out" Casaubon as a narcissist in his own right because he is not simply "an exteriorized embodiment of a mode of imagination threateningly antithetical to hers." ${ }^{14}$ He also stands as a figure of emotional illegibility, which the moral imagination can never fully ignore or triumph over.

For Hertz, identification tends to blur boundaries and erode capacities for differentiation between self and other. Eliot's characters seem to have permeability in their social lineaments, the quality that, I have been arguing, has so greatly confounded readers of James's late fiction. The difference is not that Eliot fails to account for complex identifications by conceding a premature contrast between Dorothea and Casaubon. It is that her decided belief in the ultimate goodness of human connection seems to weather all possible conditions and to triumph over any possible check, almost before relationships have a chance to fail. It is no accident that Hertz seems to spend most of his book focusing on Eliot's marginal characters, since it is with them that the author risks an exploration of social failure. Still, that risk is not taken as far as it might, and one gen- 
erally sees Eliot edging toward a vague recovery process for the characters she has not banished from the narrative. ${ }^{15}$

The problem with Eliot's approach to characterization, as James complained of it, was that "she proceeds from the abstract to the concrete; that her figures and situations are evolved, as the phrase is, from her moral consciousness, and are only indirectly the products of observation. ... The world was, first and foremost, for George Eliot, the moral, the intellectual world; the personal spectacle came after." ${ }^{16}$ This does not mean that Eliot simply dressed up abstract moral qualities and called them people; it is more that her characters could not but reveal within their own unique desires the orderly nature of a society that refuses social and moral fragmentation.

Middlemarch's diffuseness, as James labeled it, is a consequence of the conception of society its form tries to capture. Relations in the novel are themselves diffuse and undefined-working, evidently, but without adequate dramatic proof of what they accomplish or to what they lead. Eliot must simply insist upon them as a precondition of her sometimes anxious moral idealism. We have to assume that Dorothea's kindness or Lydgate's liberality has ultimate, though dispersed, effects. In other words, we must assume a structured social world of interlocking relationships. As Leo Bersani argues, Eliot "won't abandon the dream of structured significance" - a society whose idealized unity and orderliness are already preserved for it in advance- - "even if she has to sustain it by the vague doctrine of individual goodness finally, in some way, affecting the course of history, or by the more desperate move of showing how the very subversion of her protagonists' dreams is itself a proof of the interconnectedness in life." ${ }^{17}$ The desires of characters are themselves structured by and mirrored in a tissue of already fashioned communities. If characters change, it is because they come up against this matrix of preexisting relationships and find themselves needing to adjust. The saving power of human connection is the seed of communal life that remains even when specific communities totter before the flows of history and threaten to founder.

James, on the other hand, wishes to show not only how characters change as they confront social reality, but-since reality itself is only the sum of the improvised and unprepared connections to it-how the social sphere

15. For Hertz, the trace that remains of certain marginal characters-and their disturbing presence in the narrative-offers an allegory of the equivocal nature of signification itself, "the open and indeterminate self-dispersion associated with a plurality of signs or with the plurality of interpretations that writing can provoke" (ibid., 30-31).

16. Henry James, "The Life of George Eliot," in The Critical Muse: Selected Literary Criticism, ed. Roger Gard (New York: Penguin, 1987), 208.

17. Leo Bersani, A Future for Astyanax: Character and Desire in Literature (New York: Columbia University Press, 1984), 64. 
remains open to transformation as individual agents access and modify it. Genuine change cannot be anticipated or established outside of the ways people steer a course through their situation. In fact, for James, change may be the only constant. To call James a situational novelist, then, is ultimately to state that he does something different with character from his nineteenth-century precedents. His modes of characterization are also different, as we shall see, from those of Conrad, his junior by fourteen years, whose modernist credentials are more confidently burnished but whose early writing, in my opinion, has roots in moral Romanticism.

TRANSGEN DENTAL SUBJECTIVITY, IMPROVISING INTELLIGENGE: THE CASE OF CONRAD

In Modernism and the Fate of Individuality, Michael Levenson compares the plot of The Ambassadors and that of Heart of Darkness (1899): "The two works share... most notably, the confrontation between cultures, the 'sharp rupture of an identity,' and the transvaluation of values." 18 "Both Marlow and Strether," Levenson notes, "take exceptional pains to preserve their integrity within morally suspect contexts" (3), though, at the same time, the protagonists cannot simply stand apart from communal norms: "The very attempt to extricate moral character from these cruelties [of social life] shows how the ego is composed by the social body, and how much flesh must be torn if it is to stand alone" (58). The affinity between the two novelists features centrally in Levenson's account of early modernism. Focusing on Lord Jim (1900), a novel written directly after Heart of Darkness and fashioned along similar principles, I would like to argue, however, that Conrad differs from James in his understanding of character and his conception of what insures or awakens ethical conduct. It should not be surprising that James did not react well to Conrad's "obscuration" of character, his way of sharpening suspense by invoking "a mystic impulse from within" 19 - a description James offered in a review that led to hurt feelings on Conrad's part. ${ }^{20}$

The two writers offer separate versions of what might be described as impulse-driven character. The impulses that concern James are not merely visceral but are the products of alert, open, agile minds, minds intent upon overcoming their bewilderment and avoiding obtuseness. Conrad's Jim is not nearly as refined as Strether, Charlotte, or Amerigo or inclined to the same demonstrations of sociability. However, like James's protagonists, his

18. Michael Levenson, Modernism and the Fate of Individuality: Character and Novelistic Form from Conrad to Woolf (Cambridge University Press, 1991), 3.

19. Henry James, "The New Novel," in Gard, Critical Muse, 610.

20. See Roger Gard’s headnote to James, "New Novel," 595. 
actions do bring about consequences of potentially urgent social significance. Jim establishes himself in the narrative as something of a puzzle. In the capacity of first mate of the Patna, the British officer disregards his duty to inform some 800 variously dark-skinned passengers on board of his conviction that the vessel is in imminent danger of sinking. He and other officers abandon ship, avoiding the melee awaiting the remaining passengers aboard when they realize there are too few boats to accommodate everyone. This cowardly but confounding act, which "cuts him off from the rest of his kind," then becomes the symptom of a hidden cause lodged in the hinder parts of Jim's character. ${ }^{21}$ The impulse giving rise to Jim's ethical lapse, which on the surface points to the almost criminal selfishness of the man, refuses to add up to a coherent picture, however. Interpretations of motive never achieve a seamless fit with the willful idiosyncrasy of Jim's acts, even if excuses are not necessarily to be found that pardon those acts: "The views [Jim] let me have of himself were like those glimpses through the shifting rents in a thick fog-bits of vivid and vanishing detail, giving no connected idea of the general aspect of a country." ${ }^{22}$ Conrad spends the rest of the novel excavating the grounds and motives of his action.

While Conrad treats impulses as part of a pattern that emerges from a disguised "interior" source, James regards his characters' exertions as a productive series of improvisations whose implications the narrative hopes to work out or fine-tune. Clearly a subtle line separates the two versions of character. In Conrad's case, character is subject to an intense hermeneutic demand. Marlow, the narrator, obsesses over the degree to which Jim's puzzling, impetuous actions can be linked to an essential facet of his personality. The appalling surface of appearance becomes an invitation to analyze buried motives or deep structures of the self. Marlow follows a logic of substitution whereby any manifestation of an act refers itself to a prior act and to the psychological design "behind" it that makes it readable. Ultimately, analysis ends up stalled, unable to bridge the irremediable divide between surface action and the unfathomable subjectivity that sets it in motion. Conrad's novel thus foregrounds the insistent questioning of the interpreter-in this case, Marlow, who is a proxy for the reader. The impression of Jim that Conrad registers through Marlow-like all impressionists' "bid for immediacy" — ends up in Jesse Matz's terms "featuring the byproducts of the failure to get it." 23

21. Joseph Conrad, Lord Jim (New York: Bantam, 1965), 19.

22. Ibid., 48.

23. Jesse Matz, Literary Impressionism and Modernist Aesthetics (Cambridge University Press, 2001), 11. Unlike Conrad, James conceives of impressions as augmenting or altering reality, if only because they create new avenues of possible response to what one sees. Matz's account neglects the vitalistic ontology underpinning James's proposition that "fiction is an impression" (1), especially the implication that impressions do not just bear upon the past but on a 
In 1975, Tzvetan Todorov suggested that the psychological and moral center that Marlow travels in search of in Heart of Darkness is "empty." 24 Various deconstructionist readings have taken up the idea, suggesting that the novel resists plumbing its characters for meaning or explanation, dramatizing instead an intrinsic perplexity about character itself. ${ }^{25}$ Geoffrey Harpham proposes that Conrad's twentieth-century critics assimilated him too quickly "to Freud and the general notion of the unconscious," and that the real issue is not character penetration but identification-specifically Marlow's "ambiguous, passionate, and nonreciprocal" identifications with characters like Jim and Kurtz: "The general idea Marlow 'represents' is that boundaries between people are porous and transgressable - that identity is fluid and less crystallized or "mastered' than we generally think." ${ }^{26}$ It is not obvious to me, however, why the unconscious does not apply as a suitable explanation for the identifications he has in mind, or why he resorts to new terms like "surconscious" to describe Marlow's "involuntary and traumatic" recognitions of confraternity, except perhaps because he believes that Conrad is skeptical of finding something positive or substantial in the structural interior (what Lacan would call the "real"). ${ }^{27}$ At any rate, Conradian character demands to be interpreted, and the resistance it poses to interpretation makes one feel the charge of the demand. Clearly it is worth connecting the solicitation to interpretation-and the investments entailed therein-with the failing results.

In Lord Jim, I want to suggest, ethical life consists in awakening to the fact that surface demonstrations of character do not adequately present or encapsulate the moral basis of action, the "supersensible" freedom that Kant claimed to be at the core of agency. Character exceeds all attempts to resolve or grasp it and retains a transcendental aura of sublimity that makes of all empirical facts a deceiving or impossible measure of the force of the

reality yet unmade. As James famously says in "The Art of Fiction"-in a passage that Matz and I read differently- "Experience is never limited, and it is never complete" (Henry James, "The Art of Fiction," in Gard, Critical Muse, 194).

24. Tzvetan Todorov, Genres in Discourse, trans. Catherine Porter (Cambridge University Press, 1990), 111.

25. See J. Hillis Miller, Poets of Reality (Cambridge, MA: Harvard University Press, 1965), and his later statement, "Heart of Darkness Revisited," in Conrad Revisited: Essays for the Eighties, ed. Ross C. Murfin (Tuscaloosa: University of Alabama Press, 1985), 31-50. See also Perry Meisel, "Decentering Heart of Darkness," Modern Language Studies 8 (1978): 20-28; and Arnold Krupat, "Antonymy, Language, and Value in Conrad's Heart of Darkness," The Missouri Review 3 (1979): 63-85.

26. Geoffrey Galt Harpham, "Beyond Mastery: The Future of Conrad's Beginnings," in Conrad in the Twenty-First Century: Contemporary Approaches and Perspectives, ed. Carola M. Kaplan, Peter Lancelot Mallois, and Andrea White (New York: Routledge, 2005), 33, 20.

27. Ibid., 35. Harpham cites Lacan in his book on Conrad, suggesting that he is not entirely averse to the deployment of psychoanalytic concepts. See Geoffrey Galt Harpham, One of Us: The Mastery of Joseph Conrad (University of Chicago Press, 1997), 12. 
person. If Conrad fails to discover a coherent structure of desire that organizes identity, he insists on a higher definition of human integrity, namely, the capacity to act autonomously, a power that he posits apart from any specific circumstance. In this sense, Conrad's account of moral life is exactly the opposite of the one Levenson attributes to him when he suggests that the author's language is bent upon collapsing fact and value, or empirical description and moral appraisal. ${ }^{28}$ In the case of Lord Jim, any contingent understanding of Jim's motives may suffice as a local claim to knowledge on Marlow's part, but it leaves the sensible unity of Jim's character unresolved. Conrad aims for a "total" account of character; this is why he privileges last words and final acts. Yet passionate inquiry requires that one give up on empirical sensibility as a means of fathoming it: "Are not our lives too short for that full utterance which through all our stammerings is of course our only and abiding intention?" ${ }^{29}$ Like less metaphorical forms of utterance-Kurtz's “The Horror! the Horror!” for instance-language signals or gestures at something beyond linguistic competence, dissolving at key moments into a cry or stutter, "no more than a breath," at the vanishing point of reference. ${ }^{30}$ In the vein of his Romantic counterparts, Conrad has to use language to evoke what cannot be directly represented: a transcendental capacity for freedom that commonsense understandings cannot grasp directly.

According to William Bonney, Conrad is obsessed with the thematics of suspense or suspension, "wherein all attempts to act against status quo imperial capitalism are systematically disallowed, suspended, in a paralyzing miasma of existential and psychological confusions." ${ }^{31}$ Bonney points out that the motif of suspension recurs throughout Conrad's career. But the suspensions that Conrad explores are not, as they are in James, meant as a preliminary to action or an accompaniment of it. The actions never come; Conrad's politics contemplate "the reinscription or deconstruction of ideas which, regardless, remain suspended in the ineffectual realm of discourse." ${ }^{2}$ His uncertainties about the consequences of human acts often have to do with the contradictions he sees between human freedom in all of its moral ambiguity and ruinous-because deluded-idealizations of integrity that are driven by ideology.

28. "The thought that moral life is not superimposed on experience, that the authority of the moral beyond already lies securely within the domain of fact, and that in order to pursue value we need only perceive with acuity-this thought is central to the workings of [Heart of Darkness]" (Levenson, Modernism, 56).

29. Conrad, Lord Jim, 145.

30. Joseph Conrad, Heart of Darkness, ed. Paul B. Armstrong (New York: Norton, 2006), 69.

31. William W. Bonney, "Suspended," in Kaplan, Mallois, and White, Conrad in the Twenty-First Century, 175.

32. Ibid., 176. 
Despite obvious parallels, the difference between James's and Conrad's handling of character should be apparent. In James, one cannot attribute the implications of an event to the isolated intention of any protagonist, but not because intentions, irrespective of the situation, crumble and perish at the bottom of an immense and formless cradle of agency. Instead, he depicts motives and desires as embryonic distillations of some quite definite process of coming to an insight or an understanding. For James, meanings assume a kind of holding pattern as characters seek out possible ways of clarifying or anchoring them in actions that are still in progress. In other words, James's meanings generally point at the future, whereas in Conrad, they are aimed, if anywhere, in a backward-looking direction. Conrad teases readers with the possibility of discovering the antecedents of a character's intentions (the integrity of personality underneath the veil) or, barring that possibility, of glimpsing the transcendent kernel that lies behind the situation and is reflected only indirectly in itas moonshine reflects and diffuses rays emitted by another source (this being one of Conrad's most celebrated metaphors in Heart of Darkness). The desires that James portrays, on the other hand, are situation specific and rarely descend into the allegorical generalities of Heart of Darkness or Lord Jim. ${ }^{33}$

\section{THE SOCIAL CHARACTER OF INTENTIONALITY}

Eliot and Conrad rely on different standards of consistency as a basis for defining character, but both suggest a predetermined quality absent in James. Eliot thinks that her characters' lives are held together by inescapable social ties. Situations tend merely to prove that personal destiny, inscribed in desire itself, is commensurable with, or at least bound to, the fixed necessity of structured human relations. Conrad, by contrast, sets out to expose the ideology at issue in presuming such a necessity. One cannot take for granted that communal norms establish a coherent foundation for ethical life because the social body is composed of highly variable and conflictual interests. Yet the specific intentions of Conrad's heroic characters are just as likely to be disinterested as self-interested-referring back to a ground of freedom that diminishes all actions' psychological claim to inevitability. On the other hand, by exposing the erratic side of human behavior, Conrad also bears witness to the kernel of autonomy that bears fruit in his characters' surprising actions. This autonomy guarantees, if not consistent action, then a mysterious dignity of action.

James does not assume that there is a preconceived unity to character; on the other hand, he thinks it possible to fashion a consistent or contin- 
uous ground for action. Human freedom, for him, is not so much erratic as interactive. Rather than seeking a constant set of characteristics or capacities that define a self across different environments, he examines selfhood as a series of contacts, relations, and tensions with those environments. As I have already suggested, there is something emergent within those relations that-in order to be grasped-require James's protagonists to suspend or forestall their actions at crucial narrative moments. Before going on to situate James's standard of consistency via vitalist psychology, I would like to examine some specific moments of suspended agency in The Golden Bowl to flesh out how they arise from the interactive or socially defined character of the situations at hand.

As book 2 opens, Maggie's nascent recognitions about the compromised state of her marriage-her feeling of being passed around like a "dressed doll" while another drama is unfolding out of her sight-take the form of "instinctive postponements of reflection" $(G B, 274,245)$. She finds herself, in James's metaphor, circling around her situation as though it were a pagoda too imposing and too impenetrable to enter directly. Later she dismisses the immediate impulse to denounce Charlotte, which "reigned for her ... [as] that fascination of the monstrous, that temptation of the horribly possible" ( $G B, 383)$. Maggie's suspensions are the most significant in the book, but similar instances of forestalled agency occur in the other leading characters-for instance, in the prince's effort not to react in haste to Charlotte's initial appearance prior to his marriage, or, for that matter, the efforts on the part of Charlotte, Adam Verver, or the prince to delay a reaction at various moments of confusion or irresolution. Characters do not merely hold off acting in order to catch up with their situation; they put off determining exactly where their own or others' interests lie, and even, as I have been suggesting, to some degree what they desire.

These moments of delay or suspension are due, in part, to the fact that interests are mutually entangled within the situation. Maggie cannot act, of course, without sacrificing her father in the process, which she is loath to do. Additionally, and perhaps even more fundamentally, James suggests that something about the involvement of one character with another's fate disrupts normal ways of marking boundaries between people and apportioning interests. The philosopher Robert Pippin has offered the most serious recent consideration of the profound moral dilemmas that emerge in James's novels when, in a term he adopts from James, all meanings are "negotiated," and when one consciousness is perforce reliant on another. ${ }^{34}$ Pippin emphasizes two points that bear upon

34. Robert Pippin, Henry James and Modern Moral Life (Cambridge University Press, 2000), 64, hereafter cited parenthetically as $\mathrm{HJ}$. 
what he calls the social character of intentionality: first, that a person's identity achieves definition through its dependencies on others; second, that these dependencies are not abstract claims to special rights that are granted regardless of the situation. In other words, Pippin's James is no Kantian. James depicts forms of dependency that are felt in characters' activities, in their complex engagements with other people, and in the resulting social configurations they erect and settle upon. In Pippin's description, consciousness is not simply "of" something; in James, it is consciousness of somebody's consciousness of you. He describes James's ambitious effort to challenge cognitive schemas that claim to describe how beliefs and intentions are structured. Pippin's account seems right, as far as it goes. But I want to take a slightly different direction by showing how these suspensions of interest as well as of agency are not only a source of deep ethical worry for James but also a crucial, affirmative element of ethical life.

To get a better sense both of Pippin's insight and of where I differ, it is worth dwelling for a moment on his account of the scene between Adam Verver and his daughter in the billiard room at Fawns. Verver has retreated to this room to hide from the fortune-hunting women who he is afraid are after him now that Maggie, his daughter, is married and, having no public claim upon his attention, can no longer shield him from their pursuit. The thing that Pippin seizes on is the "mute passage" between father and daughter:

At the very moment when this "silent explosion" of revelation occurs, when Adam sees that Maggie sees him now as a newly independent agent in their relation, he suddenly and for the first time realizes this fact and its many possible implications for himself, but again, only through or because of seeing it in her. . . Maggie ... also sees that her father sees this in her, realizes that he has seen her view of him in this new way, and the implication is that her relation to him will now change because he will see from now on that she has this new concern. ... And as if all these gymnastics weren't enough, James doesn't leave it there. For not only do they come to see each other differently through or by means of these perceptions and perceptions of perceptions, they both come to see how their relation to each other as a couple in the world has altered by seeing that they are both seen in a new way. (HJ, 75)

Oddly, James renders this moment of the father's awareness of separation from his daughter, which Pippin admirably paraphrases, by showing how he experiences it through her, understanding its ramifications for her. Pippin worries that such moments create agents who are insufficiently individuated; they cannot settle on discrete conceptions of their well-being or exert their free mutuality. Adam and Maggie's dependen- 
cies therefore "might seem to threaten to dissolve the integrity of any self into its social constitution" (HJ, 126).

Before simply labeling James's characteristic representation of extravagantly interconnected interests as a "great moral crash" (HJ, 77), it is worth noting that Verver's exchange of looks leads him soon after to a specific action, that of contemplating marriage, settling on that course in order to spare his daughter worry about his vulnerability to grasping, calculating women. However misguided Verver's eventual crystallization of motives, his action originates in a moment of lingering impressions, which leads him to restore equilibrium to his tangle of relations by rendering his own interests permeable. James thinks that social solutions, good or bad, come not from people removing themselves from the mesh of their relations but only from their substituting one set of relations for another. But in order to figure out what these sometimes subtle and mutable forms of affiliation are or could be, individuals are required to trace them out by feeling how their thoughts reverberate upon their confederates, while also temporarily suspending action. The failure to start out with explicit motives or interests does not prevent people from acting forcefully at some later point in a situation. In their early confusion, though, characters often proceed through incremental adjustments or improvised impulses (even if these end up having far-reaching effects), such as whenin the book's most prominent example-Maggie decides not to confront Charlotte or the prince directly after learning of an affair merely by sensing an alteration in her relation to her husband and, instead, begins to make small changes to her marital routine.

The itinerary of Pippin's argument offers interesting parallels to vitalist theories. I draw attention to the connection because, as it seems to me, Henry James relies on a broadly vitalistic conception of agency. James's presumption, like Bergson's, is that people are guided by impulses and are thrust into action before they have a chance to register all the relations forming around them. For his part, Pippin thinks that the understandings that James's characters attain in social life are not isolated cognitive attitudes or beliefs but involve dispositions to act: "What looks like 'an awareness' [in the sort of society of The Golden Bowl] turns out to be much more provisional and temporally unstable, often as much an uncertain, hesitant anticipation of another's understanding as anything that could be described cognitively, often as much a first draft of an intention, something that comes to clarity, necessarily, only long after the deed" (HJ, 16-17). Pippin ends up seeing things in much the same way as Bergson does. Compare the foregoing account with Bergson's way of conceptualizing perception. The world, for him, simply consists of what he calls images. When one perceives, one does not illuminate those images or extract a representation from them; matter is not radically distinct from 
one's perception of it. The difference is that "my perception displays, in the midst of the image world, as would their outward reflection or shadow, the eventual or possible actions of my body." Thus perception allows me to prepare "the reaction of my body to the action of external objects." 35 Both philosophers consider perception to be a way of refracting the whole field of relations through the prism of one's provisional or possible action. A perception is always halfway toward an intention or a tendency toward action, or something clarified by an intention or tendency. On this view, the emphasis is on how people interrogate their feelings by inclining to act in a particular way and thus alighting upon intentions or working them out. As Bergson argues, to perceive something is to make one kind of pragmatic incision into experience. Perceptions isolate and simplify experience, putting complicated relations into useful shorthand that allows one to make difficult decisions. ${ }^{36}$

To go back to Henry James, the perceptions explored in his fiction have something of the nebulousness of future possibilities inscribed within them. Because they hinge on dense social transactions, they are even more than customarily incomplete or unfinished. Something anticipatory presents itself in James's rendering of consciousness that cannot be captured in a single moment extracted from the continuum, and which any description would render only rudimentarily, by finding dots to connect where there is a sea of forces. Hence James begins the chapter following the exchange of glances between Verver and Maggie with a vitalistic image of the consequences: "So much mute communication was doubtless, all this time, marvellous, and we may confess to having perhaps read into the scene, prematurely, a critical character that took longer to develop. Yet the quiet hour of reunion enjoyed that afternoon by the father and the daughter did really little else than deal with the elements definitely presented to each in the vibration produced by the return of the church-goers" ( $G B, 92)$. James plays up vibrations and their reverberations, not a spontaneous understanding, though he does rule out the former's leading to the latter.

In many respects Pippin's account follows Bergsonian lines, but his emphasis incurs a vitalist objection: he accentuates the role that beliefs play as intermediaries of action. His underestimation of James's fluid and ambiguous situations has to do with his sense that consciousness

35. Henri Bergson, Matter and Memory, trans. N. M. Paul and W. S. Palmer (New York: Zone, 1991), 22, 23.

36. Bergson thinks that perceptions make actions manageable, even if they also potentially distort the world by simplifying and schematizing it, patterning an impression on remembered objects. They are "'signs' that recall to us former images. The convenience and the rapidity of perception are bought at this price; but hence also springs every kind of illusion" (ibid., 33). 
requires clear guideposts for enabling social exchange. ${ }^{37}$ Beliefs about other people's motives do this work: they introduce a "normative dimension of meaning and intelligibility" into everyday discriminations and enable rituals of interaction and communication (HJ, 66). Bergson, on the other hand, stresses action above cognition and a drama of doing over a drama of understanding. Pippin, like many other James scholars, is not a strict cognitivist who universally demands a clear discursive basis for assessing intentions, and he readily accepts the possibility that the novelty of certain experiences may make evaluation of them difficult, but he focuses on the particular understandings that James's characters come to have or fail to have of one another, rather than the social world they build or the forms of relationship they set in motion. ${ }^{38} \mathrm{He}$ gives priority to epistemic over action-oriented criteria for gauging situations.

For Bergson and, I would argue, for Henry James, to give primacy to beliefs or fixed assessments of a situation is to live at an intellectual distance from the world. ${ }^{39}$ Beliefs about motive are incapable of keeping up with the variegated relations between people. In James, one might even say that explicit judgments, reasoned assessments, and defined attitudes seem to get in the way of a more primary intuitive analysis of one's own relations to another, as they decompose and recompose in ways not amenable to causal or rational accounting. The qualities of insight that James respects seem to have a lot to do with how characters seize upon certain kinds of salience, how they settle upon one set of approximate possibilities at the expense of another, and finally how they orient or adhere to their choices as they attempt to reconfigure their current situation. He is preoccupied by a protagonist's manner of attending to a thing rather than the strictly theoretical question of what the character knows or believes.

37. Pippin thinks that beliefs confer trust and conviction in the institutions, practices, and traditions that convey meaning. They allow one to assess "the rightness of actions" (HJ, 66) by confirming or envisaging realistic interpretations of them. He isolates a problem endemic to a secular, self-interested society: people have difficulty assigning meaning and locating authority, which leads to troubles assessing one another's aims and undertakings on the basis of their fit with available normative contexts.

38. For examples of other critics who display a similar emphasis, see Jonathan Levin, who turns to "gaps in [characters'] communication," things left "unsaid" (Poetics of Transition, 144); or Sharon Cameron, who describes the impossibility in James of having "shared reference" (Thinking in Henry James [University of Chicago Press, 1989], 95).

39. See, for instance, Bergson's attempt to mark out and celebrate what is most radical in the philosophy of William James: "For him those truths it is most important for us to know, are truths which have been felt and experienced before being thought." Rather than regard true assessments of reality as working on the basis of a "resemblance of a portrait to the model," we have to adopt a pragmatic relationship to a reality that "is singular ... [and] changing" (Henri Bergson, "On the Pragmatism of William James," in Creative Mind: An Introduction to Metaphysics [New York: Carol, 1992], 213). 


\section{RELATIONAL BEING}

To the extent that James's protagonists elude a substantialist standard of consistency-one based on psychic structures that predetermine identity-a number of critics have taken his late novels as evidence of ethical life gone awry. Even Pippin, who regards James as offering a plausible moral psychology, thinks that James's "sophisticated world of supremely intelligent mirrors" leaves the core of character or the autonomous heart "too weak to do much pumping, too endlessly qualifiable, to serve any real moral, judgmental purpose" $(H J, 86,127)$. What such viewpoints overlook is the possibility of alternative parameters of characterization, ones that, I argue, are based on a "superficial" but credible vitalist standard.

The challenges that critics mount to Jamesian character have tended to veer in contrary directions, which one could label the arelational and the hyperrelational account of consciousness. Yet this divergence may ultimately be less revealing than the places where these critics converge. Sharon Cameron and Leo Bersani offer influential versions of these paradigmatic alternatives. Both critics end up claiming that James's solutions do not obey realist strictures, while I want to see him as breaking ground for a new kind of realism. According to Bersani, James "dramatizes the possibility of an intentionality unsupported by motive, that is, of a desiring self so responsive and so indefinite that it is created entirely (but never limited) by the responses to its performances." ${ }^{40} \mathrm{He}$ suggests that this desiring self diffuses itself into what amounts to a set of linguistic performances detached from psychology. "Language" in James "would no longer reveal character or refer to desires "behind' words"; the "I" merely becomes a "neutral territory" that is "by nature always 'outside' any particular self." Cameron, on the other hand, argues that consciousness is given the power to define rather than attune itself to the situation around it. Jamesian consciousness is so all-encompassing and arelational that it swallows up any opposing perspective.

Since James depicts characters whose identity is not dependent on any solid, interior foundation, Cameron simply concludes that he releases consciousness from empirical constraint, either by evacuating all other

40. Bersani, Future for Astyanax, 137.

41. Ibid., 137, 146. Bersani's position has parallels with that of Tzvetan Todorov, who suggests that the elaborations of talk in The Awkward Age (1899), filled with indirect speech and increasingly far-flung circumlocutions, liberate language from its reference to reality. See Todorov, Genres in Discourse, 125, 126. I would suggest, however, that the conversations about conversations that Todorov finds everywhere in The Awkward Age do not insulate fiction from reality but in fact are, for James, a form of reality. Our relations to the world, our impressions of it derived from banter and casual talk, simply construct the mode of beingin-the-world of those in "society." 
persons from the scene described, as James putatively does in The American Scene (1904-7); by authorizing a single consciousness to project its own understandings onto social situations; or finally by allowing a central character's consciousness to deny shared meaning at all. She associates the latter two strategies with The Golden Bowl. Because they do not obey limits, James's characters do not amount to plausible psychological agents: "An account of consciousness as psychologized understands consciousness as a phenomenon associated with subjectivity: as internal, centered, circumscribed, fixed. Conversely, a poststructuralist account (the dominant critical alternative) critiques and dismisses the idea of such a center, conceptually replacing the structure of consciousness with the structure of the sign and then proceeding to deconstruct that. In the chapters above I read James against the traditional account of consciousness as psychologized, arguing that consciousness in James's novels is not internal, not centered, not associated with subjectivity." ${ }^{42}$ Cameron refurbishes the critical bias against psychological approaches by approving a poststructuralist framework. But by lumping all "traditional accounts" of psychology together, she ignores many alternative psychological theories of the period, including the one presented by James's own brother. If, as Cameron says, consciousness in late James exerts "magical claims"-if James divorces power from any realistic exercise of it-then he succeeds only in hypostatizing the imagination. ${ }^{43}$ Her account would seem to demonstrate that consciousness in James is little short of delusional, ignoring at great peril what Freud would call the Reality Principle. In any case, Cameron, like other critics, seems to presume that characters such as Maggie know exactly what they want and proceed to get it. I would like to say, in contrast, that Maggie only has makeshift knowledge and must learn how to accommodate reality as much as reality has to bend to accommodate her.

For Bersani, the self-inventiveness that James dramatizes ultimately empties out all personal identity, resolving social discord by transforming personal motives into depersonalized art, therefore liberating the novel from any worry about strictly human-centered need. A reality that is resistant to easy forms of resolution-for example, the shocked betrayal that lays the dramatic foundation for The Golden Bowl-succumbs at the end to the "artistic manipulation of life's materials" as Maggie turns her marriage into a superior fiction. ${ }^{44}$ His argument contributes to a critical inclination, evident already from the time of character criticism, that either celebrates or decries-but in any case, insists upon-James's subordination of any single fictive personage's interest or point of view to a larger

42. Cameron, Thinking in Henry James, 170-71. See 102 for a summary of her argument. 43. Ibid., 41.

44. Bersani, Future for Astyanax, 146. 
aesthetic order. ${ }^{45}$ Maggie creates a new reality by absorbing everything and everyone into her artful vision and, it would seem, by recasting herself in the same way that her fictive vision recasts the lives of others.

Michael Snediker's recent effort to grapple with Bersani's argument has fruitfully updated his approach to character. While Bersani thinks that James's narrative solutions are unsatisfying because psychic life is too malleable-that is, because character remains too much in the realm of imaginary linguistic inventions-Snediker counters by inventorying the narrative elements that anchor character in a materialist way. He suggests that the consistency of James's selves is procured by their mysterious patience and by "their dependencies on the temporal." Maggie's "faith in time" enables her to repair the compromising asymmetry that has occurred in her marriage, allowing an impaired reality to bend toward a new ethical order: "Maggie's most impassioned relation is to neither her father nor her husband but to time itself. Time will determine the degree to which her fictions get to count as truth; time will determine ... the degree to which meaning will work in her favor." 46 The suggestion is helpful, but it abstracts or hypostasizes time in a peculiar way and says too little about what the measured forms of inaction he describes accomplish in the novel, except that patience-the restraint placed upon doing anything-allows characters to hold off dealing with immediate realities and prevents a catastrophic literalism from taking hold of the situation. $^{47}$

I want to follow up on my previous assertion that personality is not the only means of generating psychic consistency. Other and indeed suppler means arise from vitalist psychology. Bergson famously argues that mental states "continually [swell] with duration" and that there is no substratum to reality, no "impassive ego," to unite separate phenomenal manifestations of the same self. ${ }^{48}$ His claim bears obvious relation to William James's original formation regarding the "stream of consciousness": "Consciousness, then,

45. For examples of such character criticism, see F. O. Matthiessen, Henry James: The Major Phase (Oxford University Press, 1944); and Laurence B. Holland, The Expense of Vision: Essays on the Craft of Henry James (Baltimore: Johns Hopkins University Press, 1982). To see the recurrence and remobilization of claims about the aesthetic nature of James's novelistic resolutions, see Jonathan Freedman, Professions of Taste: Henry James, British Aestheticism, and Commodity Culture (Stanford University Press, 1990). See also F. R. Leavis, who argues that our sympathy ought to lie with Charlotte and Adam Verver and that James, who clearly weighs the case otherwise, may have lost his moral sense in his elaborate oversubtlety (F. R. Leavis, The Great Tradition: George Eliot, Henry James, Joseph Conrad [London: Chatto \& Windus, 1948], 159-63).

46. Michael Snediker, "Stasis and Verve: Henry James and the Fictions of Patience," The Henry James Review 27 (2006): 25.

47. Ibid., 40.

48. Bergson, Creative Evolution, 2, 4. 
does not appear to itself chopped up in bits. Such words as 'chain' or 'train' do not describe it fitly as it presents itself in the first instance. It is nothing jointed; it flows. A 'river' or a 'stream' are the metaphors by which it is most naturally described. In talking of it hereafter, let us call it the stream of thought, of consciousness, or of subjective life." "James avails himself of the "stream" metaphor in order to describe what is continuous and "without breach, crack, or division" in psychic life. ${ }^{50}$ Instead of positing an abstract sameness at the core of identity, he, like Bergson, propounds psychic models grounded only in continuity. For his part, Bergson suggests that "an ego which does not change does not endure," playing on the etymological propinquity to the term "duration" and suggesting that only things with a plastic quality can survive the test of time. ${ }^{51}$

Less often cited, though integral to understanding what James means by stream of thought, is the statement he settles upon to explain the form of coordination among thoughts: "Each pulse of cognitive consciousness, each Thought, dies away and is replaced by another. The other, among the things it knows, knows its own predecessor, greets it, saying: 'Thou art mine, and part of the same self with me.' Each later Thought, knowing and including thus the Thoughts which went before, is the final receptacle-and appropriating them is the final owner-of all that they contain and own. Each Thought is thus born an owner, and dies owned, transmitting whatever it realized as its Self to its own later proprietor." ${ }^{25}$ Consciousness is not an "entity" but an orientation or a function, as James clarifies in a subsequent essay. ${ }^{53}$ As such, it resists objectification. As Robert D. Richardson glosses James, "We should have our eye on the process as well as-perhaps more than-the product, on the path as well as the goal." ${ }^{54}$ A stream of thought, then, is not any particular private content of a subject's experience but a process of relating or "owning" whereby a thought directs itself to its object, appropriates it, and in turn becomes appropriated. First in a position of structuring experience and framing objects in the world, a thought later dies and becomes an object to be framed. It gains its coherence not in itself but in the various relations it maintains with its objects, which then reorient it.

A stream of thought is nothing but a circuit of relations within the world. For that reason, consciousness is not an interior condition. As a

49. William James, Principles of Psychology, 2 vols. (New York: Dover, 1950), 1:239.

50. Ibid., 1:237.

51. Bergson, Creative Evolution, 4.

52. James, Principles of Psychology, 1:339.

53. See William James, "Does 'Consciousness' Exist?" in Essays in Radical Empiricism (Lincoln: University of Nebraska Press, 1996), 3-4.

54. Robert D. Richardson, William James: In the Maelstrom of American Modernism (New York: Houghton, 2006), 235. 
protophenomenologist, James moves from an eighteenth- and nineteenth-century picture of the psyche as a self-contained receptacle for mental content (ideas) and toward a model of consciousness whose consistency comes from being directed onto objects in the world. ${ }^{55} \mathrm{He}$ understands intentionality to be not a one-way process but a reciprocal activity, which does as much to determine what conscious agents are as it does to construct and give shape to what they take in. Transcendental notions of subjectivity take for granted that one has a core of unchanging structures that underlies and gives shape to one's activity, while William James sees activity, the activity of a thinking process, as the basis from which one alights upon structures (including, I would argue, structures of desire).

Both William and Henry share a conception of reality built upon the insistence, in Jonathan Levin's terms, "that nothing has its identity in itself. Everything is instead what its dynamic web of relations constitutes it as." ${ }^{56}$ Thus Henry James remarked to Hugh Walpole shortly after finishing The Ambassadors that "the whole thing ... is a picture of relations" - to which I would add, principally ones created and maintained in thought. ${ }^{57}$ Despite their disagreements, both brothers understand thought to be a reality-producing event. ${ }^{58}$ Agents are not left passive in the face of a priori structures that determine their capacity to think (as Kantian transcendentalists maintain) or passive in the face of a world of objects whose structures organize their experience (the assertion of Lockean empiricism). Consciousness involves a whole series of receptive tendencies-effort, attention, perception, and imagination-the activity of which seems to promote an active attunement to things. When Maggie breathes out to her friend Fanny her astonishing knowledge of the affair between her husband and Charlotte, James remarks that "the situation

55. For an account that appraises William James as a protophenomenologist, a conceptual and historical forerunner of Husserl (the philosopher who formalized phenomenology as a branch of philosophy), see James Edie, William James and Phenomenology (Bloomington: Indiana University Press, 1987).

56. Levin, Poetics of Transition, 122.

57. Henry James to Hugh Walpole, August 14, 1912, in The Letters of Henry James, ed. Percy Lubbock, 2 vols. (New York: Macmillan, 1920), 2:254.

58. James's sympathy with and approval of key elements of his brother William James's philosophy does not prevent them from parting company on aesthetic grounds, an issue that dominates quite a number of their letters. "Philosophically, ... I am 'with' you, almost completely," Henry writes to him (Henry James to William James, November 23, 1905, in William and Henry James: Selected Letters, ed. Ignas K. Skrupskelis and Elizabeth M. Berkeley [Charlottesville: University Press of Virginia, 1997], 467), though he also dismisses his brother's complaints about the "twilight or mustiness" in his plots, the "fencing in the dialogue," and the lack of "straightness in the style" (William James to Henry James, October 22, 1905, ibid., 463). For a fuller exploration of the complicated relationship between William and Henry James, see Ross Posnock, The Trial of Curiosity: Henry James, William James, and the Challenge of Modernity (New York: Oxford University Press, 1991). 
had changed $\ldots$ by the outbreak of the definite" $(G B, 346)$. This banal evidence of the power of thought gains considerable poignancy, however, when one realizes that even definite knowledge is merely a preliminary to establishing new and as yet undefined relations. Thus Maggie and Fanny have to keep up a thought process in which possibilities are encompassed, absorbed, and followed up on. Knowledge is not the endpoint of this process, but an invitation to think further and eventually to act. James emphasizes that the world is not given but made or fashioned.

\section{ETHICAL BREATHING ROOM}

What differentiates one consciousness from another in William James's account is the particular responsibility that we each have for our own thoughts and deeds- that is, the particular ownership we take of them, the feeling of warmth this imparts, the range of special responsibilities entailed by reflective self-consciousness, and the deliberative commitments entailed therein. Undoubtedly, his brother's fiction tests the legitimacy of this principle by presenting characters who refuse to express interests altogether detached from those of their intimates, who suspend action, and who even decline to accept explicit or public responsibility for their offenses and deeds. According to Pippin, the blurred character of psychic life-the feeling that mental activities are "somewhere 'between' and not 'in' persons" - causes James's characters to lose their psychological and moral sense of orientation (HJ,64).

As significant and interesting as Pippin's account of agency is, he does not seem to find much of affirmative value in the open-endedness of Jamesian situations. Yet these are precisely the source of imaginative interest for James and for his characters. What they do is to render people unable to fall back on convenient interpretations and preconceived attitudes. James boosts or enhances the dignity of all persons willing to submit to the interpretive suspensions that prevent easy moralistic judgments. These suspensions do not, however, stop protagonists from taking a directed course of action or, once having understood their situation, from drawing fine distinctions between their own interests and responsibilities and those of others. It is very easy to overstate the degree to which his characters are subject to a flux of dilute and unbounded identity. ${ }^{59}$

59. Joseph Litvak explores the concept of theatrical performance as a way of "unpack [ing] subjectivity" by denaturalizing it, thus rescuing James's characters from fixed subject positions (Caught in the Act: Theatricality in the Nineteenth-Century English Novel [Berkeley: University of California Press, 1992], xii). Leland Person, too, stresses the fluidity of social and gender roles, describing their suspension through performance, which allows male characters (his specific focus) "improvisational freedom to construct a masculine self from a range of possibilities" (Henry James and the Suspense of Masculinity [Philadelphia: University 
James is not the author of limitless self-expansion, as both Bersani and Cameron suppose in their ways.

I want to suggest that deferral of responsibility is not tantamount to an abdication of its claims. If we return to the exchange of glances between Adam Verver and his daughter, the moment of awareness concerns the feeling that his daughter has come to be a "distinct thing" from him $(G B, 91)$. In principle, at least, Verver sets out with a recognition of his own and his daughter's separate responsibilities. Individuation is felt in terms of the discrete interests that swarm around people as centers of agency. Nevertheless, the complications present themselves the moment Maggie's father enters into a marriage without seeming to make a claim for his own needs or desires, undertaking the step simply to assuage her concern over his vulnerability. James insists that all interests are social in nature, but that does not mean that they are symmetrically apportioned among parties. Sometimes James's characters go too far in the direction of suspending their own interests and responsibilities, but this is just one morbid extreme, the flip side of a psychology that upends so many truisms about American individualism. Adam may be said to collapse his interest with Maggie's at an odd but crucial moment and so fail to see distinctions that are personally and socially necessary. The initial problem is not that he sees his duties in relation to his daughter but that his act of overidentification oddly instrumentalizes his own position and, by extension, that of his future wife. This is as fatal an act as too close an adherence to private interests. Charlotte-the woman he weds-placed as she is between Maggie and her father, eventually turns to Prince Amerigo for a passionate connection otherwise foreclosed to her.

Even this eventuality is not a fait accompli from the outset. It is, however, the likely result of Adam's failure to acknowledge his difference of position from that of his daughter. "Difference of position" is not the same as complete "independence"; a Jamesian self is defined by its various relations. Charlotte and the prince pursue an affair as a response to a galling imbalance-or rather, balance-in their own lives. But they do not tell each other, and are probably incapable of telling themselves, all the things their affair means to them and those around them. As James says of Strether in The Ambassadors, another character who takes an unprecedented wait-and-see attitude to his circumstance, "I don't explain myself even to myself. How can they then understand me?" ${ }^{60}$ Charlotte

of Pennsylvania Press, 2003], 20.) But such gender criticism sometimes risks forgetting that performances require endorsements of the roles characters perform, though Person, at least, implicitly acknowledges as much in his reading of The Golden Bowl, where Maggie and Amerigo's "gender identities [do not seem to] end in a state of suspense" (172).

60. James, Ambassadors, 432. 
and the prince risk a great deal, and they do so to oblige themselves, though not without considering their spouses. They seal their pledge to each other with a passionate kiss right at the moment that they reaffirm their responsibility to Maggie and Adam. Of course, the moment is meant to be ironic, but what may from the outside appear to be an outrageous, self-serving contradiction may also bespeak an inner earnestness on the part of the pair. James wants readers to entertain the possibility that interests normally thought to be exclusive can-from a certain perch-however perilously, coexist. ${ }^{61}$

It turns out that the prince and Charlotte both misread Maggie. Or rather, Maggie herself adjusts to the situation in unanticipated ways. Halfway through, the narrative shifts to focus on her-on her attempt to shape the implications she sees in her husband's affair. If a kind of suspension of interests is what precipitates the family discord, the same open-ended stance and the imaginative identifications it promotes allow resolution of the conflict by enabling a number of painful but indispensable social accommodations. Maggie forgoes the opportunity to denounce her husband and Charlotte, whatever liberty she might claim as a betrayed wife. Neither she and her father, nor the Prince and Charlotte, immediately act upon their own responsibility. It is as though, for any workable social resolution to materialize, some process of deferral must take place so that each party is in a position to rethink his or her interests and responsibilities for the situation by entertaining a new perspective. In order for this process to happen, no one may assume any immediate prerogative to act in self-interest-partly because each character is checked by fearsome eventualities that seem to loom before any definitive act. The "instinctive postponements" are recognized and mutually felt between Maggie and the prince: "What befell, however, was that even while she [Maggie] thus waited she felt herself present at a process taking place rather deeper within [Amerigo] than the occasion on the whole, appeared to require-a process of weighing something in the balance, of considering, deciding, dismissing" ( $G B, 260)$.

Maggie does not respond with anything so complete as a plan of action, and a substantial cast of critics who think otherwise have consistently exaggerated both her power and her forethought. Mark Seltzer, Jonathan Freedman, Cameron, and Pippin all think that she consciously succeeds in manipulating and dominating those around her by betraying no knowledge of her grievance, leaving Charlotte unsure of her standing

61. For an account that suggests that James's characters in The Golden Bowl affirm multiple, coexisting, and nonexclusive desires and identifications, see Judith Butler, "Capacity," in Regarding Sedgwick: Essays on Queer Culture and Critical Theory, ed. Stephen M. Barber and David L. Clark (New York: Routledge, 2002), 109-42. 
and unable to maneuver. Seltzer's and Freedman's critiques are built around a Foucauldian understanding of forms of surveillance in the novel and power structures that enforce late nineteenth-century family propriety. ${ }^{62}$ In a sense, they moralize no less than the humanist critics they set out to defy. I think such readings-though faithful to the end results of Maggie's actions - assume an unwarranted degree of knowledge on Maggie's part from the beginning, ignoring her own conscious sense of vulnerability as well as the particular costs she readily incurs in the bargain: she refuses to be acknowledged as wronged; she rejects any triumphalist rhetoric; she "gives up" her father. When Maggie sets out, she does not yet know what she wants or is willing to live with, but finds her path as she goes along.

Often James gives us characters who do not simply fail to have preconceived intentions but actively resist having them-or decline to solidify them by having them confirmed in the eyes of the world. By embracing the indistinctness of their own and other people's conduct, James's protagonists defend the means of discovering finer and more generous interpretive possibilities for understanding it. ${ }^{63}$ At least at first, Maggie finds herself affected by her situation but unable to take definitive steps. Her initial options for responding to the situation exact an unbearable price: sacrificing her father's happiness and potentially risking her own marriage. She opts instead to proceed by measured inaction. She begins to adopt a specific "expression and tone"-and invites or compels Charlotte and the prince to take their cues from her rather than from each other $(G B, 268)$. She sees that her own conscious sense of herself interests the prince, and he in turn is given the space to be interested precisely

62. "The well-policed character of the 'world' of The Golden Bowl is at once readily apparent and difficult to assess, apparent in that the novel everywhere displays the nexus of seeing, knowing, and exercising power that, I have argued, defines the politics of the Jamesian text, problematic in that police work and supervision in the novel are so thoroughly inscribed in gestures of compassion, care, and love" (Mark Seltzer, Henry James and the Art of Power [Ithaca, NY: Cornell University Press, 1984], 63). Compare Jonathan Freedman: "Maggie's counter-counter-responses range from indirection to outright prevarication, and they are neatly and cruelly calculated to present Charlotte with a façade of disingenuous ignorance and feigned innocence so perfect that it can never be penetrated or parted" (Freedman, Professions of Taste, 237).

63. I should make clear that James does not grant the exceptional openness that one observes in, say, Maggie, Charlotte, or Strether, to his "ficelles" and minor charactersFanny Assingham or Sarah Pocock. James portrays Fanny fondly, but her overbearing imagination remains a comically degraded version of that of his principal characters, while Pocock's excessively interested perspective and narrow imagination prevent her from achieving the vital incompleteness that marks James's more notable personages. For James's explanation of his use of "ficelles," see his preface to The Ambassadors, in The Art of the Novel (New York: Scribner, 1937), 322. His shorter works as well often parody the psychology he delicately bestows upon the characters of his longer novels. 
because Maggie does not attempt to qualify or define his relationship to Charlotte on her terms. Suspending her reproaches and potential aspersions, Maggie gives the prince breathing room to rethink his perspective. Her hang-fire manner and air of tentativeness prevent volatile reactions.

This suspension of direct engagement does not diminish Maggie's capacity to act; it is an extraordinary augmentation of it. Though a form of "obstructed agency" and "impassivity," her stillness does not give rise to "ugly feelings," such as those Sianne Ngai has explored. Ngai sets out to study "ambivalent situations of suspended agency," but her paradigmatic examples, such as Melville's "Bartleby the Scrivener" (1853), tend to represent forms of equivocation that are not positive or liberating. ${ }^{64}$ James too offers "a non-cathartic aesthetic" (9) and seems to parade characters before us who fit Ngai's description of having "relatively weak intentionality" (22). That is, they have emotions that "destabilize our sense of the boundary between the psyche and the world" and superficially at least disclaim autonomy (20). And yet they do not necessarily give way to resentment or invariably betray negative emotion, characterized by a diminishment of agency.

For his part, Bergson thinks that the "zone of indetermination," the pause or interval of hesitation between perception and action, multiplies the possibilities for acting. ${ }^{65}$ The better a body is capable of absorbing the connections it has to the world, the greater the repertoire of actions it can muster up. ${ }^{66}$ He defines this absorbing capacity-which momentarily suspends action-as an affection. ${ }^{67}$ Gilles Deleuze characterizes Bergson's affections as breaks in the action-reaction circuit. ${ }^{68}$ Before an action comes about as an effort directed upon things in the world and meant to influence them, affection occurs as the body's "actual effort upon itself "effort being the body's way of adjusting to possibilities, aligning its powers with them. "Consciousness means virtual action," says Bergson, and in James, this consists in extending the influence of individuals over their situation. ${ }^{69}$

Even in what most resembles a climactic scene, such as the one where Fanny Assingham shatters the golden bowl and Maggie braves an en-

64. Sianne Ngai, Ugly Feelings (Cambridge, MA: Harvard University Press, 2005), 1.

65. Bergson, Matter and Memory, 32.

66. "The greater the body's power of action (symbolized by a higher degree of complexity in the nervous system), the wider is the field that perception embraces" (ibid., 56).

67. "Now we have considered the living body as a kind of center whence is reflected on the surrounding objects the action which these objects exercise upon it: in that reflection external perception consists. But this body is not a mathematical point; it is a body, exposed. ... We might therefore say, metaphorically, that while perception measures the reflecting power of the body, affection measures its power to absorb" (ibid.).

68. Gilles Deleuze, Cinema 1: The Movement Image, trans. Hugh Tomlinson and Barbara Habberjam (Minneapolis: University of Minnesota Press, 1997), 87.

69. Bergson, Matter and Memory, 57, 50. 
counter with the prince, we get what looks finally like a removal from the abyss - a bit of backpedaling — rather than any definitive airing of feelings. Maggie considers what difference the possession of real knowledge of the affair means to her and to Amerigo:

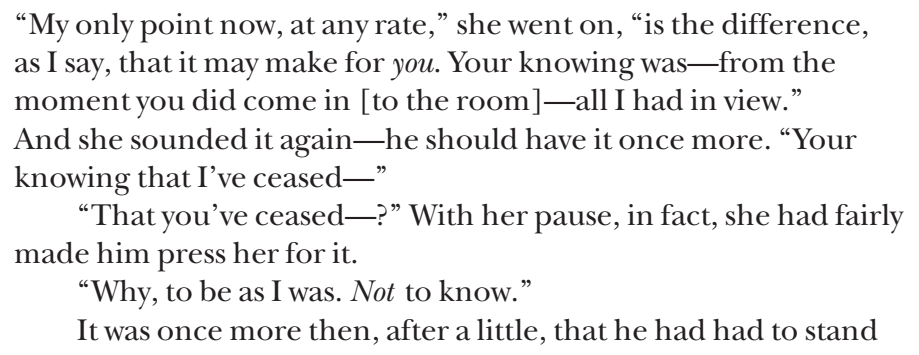
receptive. $(G B, 366)$

This dangling moment, which makes us think just for a second that Maggie will declare that she has ceased to believe in him or to love him, submits to no such expression of conclusiveness. It circles back; it says again and draws inward. And yet it betokens a deepening of the receptivity between the two.

James stakes a great deal on this receptivity. Maggie, at this moment as throughout, refuses the convenience of outraged feeling. She manages to grant the prince a definite delay before he must react: "It had operated within her now to the last intensity, her glimpse of the precious truth that by her helping [the prince], helping him to help himself, as it were, she should help him to help her" $(G B, 357)$. In this statement, her postponements, which are proffered almost as a gift on her part, also allow her to fold her own interests into those of the prince and, indeed, into those of other characters as well. The prince, in turn, reciprocates by shutting Charlotte out and by accommodating what is "definite" in her attitude. Maggie strikes an unspoken compact with Charlotte, which allows the latter to retreat with her husband without paying the price of a moral exposure. This is a disagreeable but necessary compromise. Charlotte gets sacrificed, and Maggie gives her pain a terrible, lucid tribute. She, in turn, "gives up" her father, one of only two attachments of immense fervor that she possesses.

What comes next, "foredoomed to remarkable salience," is the avowal of the significance-the impact and impression-of one person on another $(G B, 462)$. The prince is awed by the strength of character he has witnessed in his wife and expresses his wondering esteem to her. Maggie finally brings an end to any confession on her husband's part-not through an actual declaration of guilt from him (the possibility of which would only serve, Maggie is aware, to defame Charlotte at the moment of her supreme sacrifice)- 
but through a profound form of unspoken intimacy. In the dissolution of an old life-James seems to suggest—a new one, rudimentary in form, may just ease into perspective. In this, I want to claim that James offers a fully credible presentation of psychic life, in its suspensions as well as its inevitable limitations and end points, but one structured in ways that demand a more capacious and nuanced account than is currently offered by our literary language of character and our most immediate psychological models of agency. 